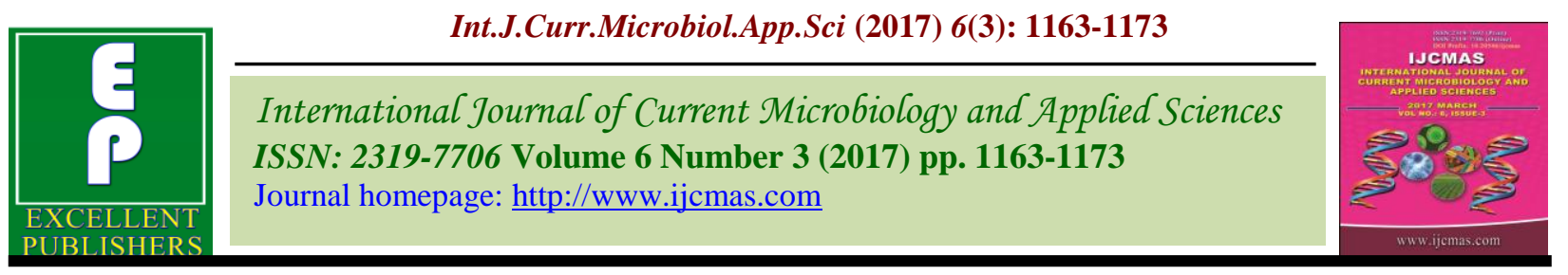

Original Research Article

https://doi.org/10.20546/ijcmas.2017.603.135

\title{
Genetics of Free Threshability and Yield Traits in Tetraploid Wheat
}

\author{
C.H. Nagaraju*, Desai, S.A. Suma, S. Biradar, Rudra Naik, V. Chetan C.K. and Sathisha \\ Department of Genetics and Plant Breeding, University of Agricultural Sciences, \\ Dharwad -580005 (Karnataka), India \\ *Corresponding author
}

\begin{tabular}{|c|c|}
\hline & A B S T R A C T \\
\hline & Attempts has made to find the inheritance pattern of free threshability and other \\
\hline Keywords & quantitative traits in emmer wheat has fragile rachis and non-free threshing kernels \\
\hline $\begin{array}{l}\text { Emmer wheat, } \\
\text { Epistasis, }\end{array}$ & $\begin{array}{l}\text { by crossing a non free threshing variety dicoccum DDK-1025, with two advanced } \\
\text { free threshable mutant lines (ML-1 and ML-2) during Rabi } 2013 \text {. Genetic systems }\end{array}$ \\
\hline Generation Mean & operating in the both the crosses were found different for most of the characters as \\
\hline $\begin{array}{l}\text { Analysis, Rachis } \\
\text { and Threshability. }\end{array}$ & $\begin{array}{l}\text { evident by differences in nature of gene action in these two crosses. Inheritance } \\
\text { pattern of free threshability found to be governed by dominance gene effects with }\end{array}$ \\
\hline Article Info & interaction effect (dominance $\mathrm{x}$ dominance). Presence of rachis is dominant to \\
\hline $\begin{array}{l}\text { Accepted: } \\
\text { 20 February } 2017 \\
\text { Available Online: } \\
10 \text { March } 2017\end{array}$ & $\begin{array}{l}\text { showed the predominance of additive gene action, most of the traits grains per } \\
\text { spike, length, spike density and grain weight effects showed dominance gene } \\
\text { action in one of the other crops. The role of epistatic components was indicated in } \\
\text { the expression of plant height and grain yield per plant. }\end{array}$ \\
\hline
\end{tabular}

Introduction

All Triticum diploid progenitors possess the non free threshing (NFT) habit, while both free-threshing (FT) and NFT forms occur in the tetraploid and the hexaploid groups (Kerber and Rowland 1974). The kernels of the NFT wheat are closely invested in the spikelet by tough tenacious glumes, lemma, and palea that are not readily detached with pressure or vigorous rubbing. Conversely, only slight rubbing or threshing action is required to separate the glumes from the spikelet of FT wheat to release its kernels. MacKey (1966) reported a polygenic system scattered through all three genomes that counteracts rachis brittleness and tough, tenacious glumes. A second system which suppresses these primitive tendencies is that of the $Q$ factor located on chromosome 5A. Inheritance studies of threshability in synthetic hexaploids and 'Canthatch' indicated that a partially dominant gene, apparently introduced from the T. tauschii parent, results in NFT spikelets. Kerber and Rowland (1974), showed dominant gene for tenacious glume, $T g$, in 2D of $T$. tauschii and $q$ inhibits the expression of free threshing habit in synthetic hexaploids. Further, understanding the gene action of the threshability is of prime importance in emmer wheat by looking to its quality traits and resistance to fungal diseases, there is a great need to develop dicoccum varieties with free threshing habit. Hence, the 
present study aimed to investigate the inheritance pattern of threshability by make use of advanced free threshable mutant lines with exceptionally high free threshability habit derived from intra specific hybridization followed by mutation.

\section{Materials and Methods}

To investigate the genetics of threshability, a non free threshable dicoccum variety DDK1025 crossed with two advanced free threshable mutant lines (ML-1 and ML-2) (salient features parents presented in table 1). The free threshable mutants parents were derived from inter-specific hybridization cum mutation (EMS and gamma rays treatments) involving 2 each parents representing emmer and durum wheat. In Kharif 2013 at IARI Regional Research Station (RRS), Wellington, Tamil Nadu back crossing to both the parents was practiced. Segregating and non segregating material was generated, which includes six generations viz., $\mathrm{P}_{1}, \mathrm{P}_{2}, \mathrm{~F}_{1}$, $\mathrm{F}_{2}, \mathrm{BC}_{1}\left(\mathrm{~F}_{1}\right.$ back crossed with $\left.\mathrm{P}_{1}\right)$ and $\mathrm{BC}_{2}\left(\mathrm{~F}_{1}\right.$ back crossed with $\mathrm{P}_{2}$ ). During Rabi 2013, evaluation of material was carried at Research and Development Farm, Ugar Khurd in Randomized Block Design (RBD) with three replications. Each replication consisted of four rows of each parent, two rows of $\mathrm{F}_{1} \mathrm{~s}, 25$ rows of $\mathrm{F}_{2} \mathrm{~S}$ and 15 rows of $\mathrm{BC}_{1}$ and $\mathrm{BC}_{2}$ of 1 $\mathrm{m}$ length. The crop was grown under irrigated conditions. The observations were recorded on plant height $(\mathrm{cm})$, number of tillers per plant, spike length $(\mathrm{cm})$, number of spikelets per spike, number of grains per spike, spike density $(\mathrm{cm})$, thousand grain weight $(\mathrm{g})$, grain yield per plant $(\mathrm{g})$, threshability and rachis from five random plants of the parents $\mathrm{P}_{1}, \mathrm{P}_{2}$ and $\mathrm{F}_{1} \mathrm{~s}$ and all the individual plants of $\mathrm{F}_{2}$, $\mathrm{BC}_{1}$ and $\mathrm{BC}_{2}$ generations. Threshability data of individual spikes was recorded after harvest. Spikes were threshed with hand, based on percentage of husked seeds obtained, classified as free threshable (0-30), medium free threshable (31-60) and hard to thresh / non free threshable (61-100) and spikes were observed for presence of rachis $(100 \%)$ and absence of rachis $(0 \%)$. The mean values, standard errors and variances of the different generations were subjected to weighted least squares analysis using the joint scaling test (Mather and Jinks, 1971) to estimate gene effects and the maximum likelihood method (Hayman, 1958) to estimate variance components to fit models of increasing complexity until an adequate description of the observed means were found as shown by non-significance in the $\chi 2$ test. The significance of genetic parameters was tested by t-test. The type of epistasis was determined only when dominance (h) and dominance $\mathrm{x}$ dominance (1) effects were significant, when these effects had the same sign the effects were complementary while different signs indicated duplicate epistasis (Kearsey and Pooni, 1996).

\section{Results and Discussion}

The observations recorded on mean, variability and other parameters were aimed firstly at eliciting information on how far these crosses can be broadly distinguished for their potentiality and secondly at determining how far the choice of parents (parental diversity) can influence quality and potentiality of the variability generated in these two crosses. Dicoccum variety DDK1025 is quite distinct with higher magnitude of variability being very taller $(92 \mathrm{~cm})$ than ML-1 $(86 \mathrm{~cm})$ but shorter then ML-2 $(101 \mathrm{~cm})$ (mean values, standard errors and variances for the analyzed traits of the two crosses are presented in table 1), high no of tillers with longer spike length, spikelets per spike and with very high grain yield per plant. But with respect to thousand grain weight and threshability it was inferior to mutant genotypes. The ML-2 had superior means in respect of trait grain number. No much 
variation in the mean performance was observed for spike density. The $F_{1}$ mean values indicated the probable role of dominance in respect of number of tillers per spike and thousand grain weights. In respect of the threshability, the character of basic interest the $F_{1}$ was rather on the lower parent side in both the crosses indicating the dominance of free threshability with unknown interaction effects. Which indicates introgression of threshability genes from female side and this was also indicating dominance of free threshable trait over hard to thresh. Back cross with the superior parent resulted in high mean value in both the crosses. The segregating population, $F_{2}$ exhibited more variability for all traits in both the crosses. Accordingly, there was a steep fall in the mean values from $F_{1}$ to $F_{2}$.

Joint scaling test of six generation means pertaining to the gene effects due to additive [d], dominance [h] and epistasis effects viz., additive $\mathrm{x}$ additive [ $i$ ], additive $\mathrm{x}$ dominance $[j]$ and dominance $\mathrm{x}$ dominance $[l]$ were estimated for grain yield and its attributes in the two crosses of wheat. The results are furnished in table 4.

Failure of additive-dominance model was evident from the significance of chi-square test indicating the presence of digenic or higher order interaction effects in governing the expression of traits in both crosses except number of tillers in first cross and spike density in other cross, where simple additive and dominance modal is sufficient for their study. For plant height it was evident that non-additive gene action dominance $x$ dominance was observed for inheritance indicating predominance of dominance effect. This is in conformity with the earlier report of Ismail et al., (2006). Perusal of gene effects revealed that additive effect $(d)$ was negative and significant which is desirable (table 4). Hence, it was responsible for reduction of height. Additive gene effect plays important role in expression of number of tillers per plant. Since, none of the interaction effects were significant suggesting that there is no scope for resorting to hybrid breeding for improving this trait. The gene effects are in agreement with earlier findings of Meena and Sastry (2003), Siddique et al., (2004) and Vanpariya et al., (2006). The inheritance of spike length appeared to be more complicated in DDK-1025 x ML-2 cross, where in all the gene effects were highly significant except additive $x$ additive effect whereas the influence of dominance gene action was highly appreciable in the cross DDK-1025 x ML-1. Wei et al., (2003), Jin Bao et al., (2004), Dhayal and Dobariya (2006) also suggested that operation of additive, dominance as well as epistatic gene action for this trait. Number of spikelets per spike with similar diversity however, the two crosses showed a different pattern of gene effects indicating the differences in the gene system operating to influence this character. Though additive as well as dominance component was significant in DDK-1025 x ML-1, the additive effect was more in magnitude. Whereas, the dominance effect was more in the cross DDK1025 x ML-2. Accordingly simple selection can be advocated for improvement of spikelets number in DDK-1025 x ML-1. While, biparental mating is expected to be more useful in DDK-1025 x ML-2 cross. Based on present investigation, it could be concluded that additive gene action plays major role in expression of spikelet number in DDK-1025 x ML-1. This inference is also supported by Wei et al., (2003), Vanppariya et al., (2006), Inamullah et al., (2006) and Vanppariya et al., (2006). Predominance of dominance effect was noticed for trait number of grains per spike in both the crosses. This was in accordance with the results of Jag et al., (2003) and Koumber and El-Gammaal (2012). 
Table.1 Salient morphological features of parents used in the present investigation

\begin{tabular}{|l|c|c|c|}
\hline \multicolumn{1}{|c|}{ Character } & DDK-1025 & ML-1 & ML-2 \\
\hline Pedigree & DDK1013/DDK1001// 278-13 & DDK-1025/200Gy/ER- & DDK-1025/HD4502/200Gy/BULK-26/07 \\
Growth habit & Erect & $24 / 07$ & Semi-erect \\
Average days to heading (days) & 67 & Semi-erect & 62 \\
Average plant height (cm) & 91.78 & 59 & 100.68 \\
Average spikelets/spike & 21 & 85.91 & 19 \\
Average grains/spike & 40.12 & 17 & 50.70 \\
Ear shape & Tapering & 39.60 & Medium club \\
Ear density & Dense & Parallel sided & Very dense \\
Ear length & Very long (10.04 cm) & Short (6.86 cm) & Medium (8.61) \\
Awn color/hairiness & Dull White / absent & Light brown / absent & Black / present \\
Grain color & Red & Amber & Red \\
Threshability & Non free threshable & Free threshable & Wree threshable \\
Rachis & Without & With \\
Avg. 1000-grain weight (g) & 44.45 & 46.19 & 49.68 \\
\hline
\end{tabular}

Table.2 Goodness of fit test for segregation of rachis in two crosses of dicoccum wheat

\begin{tabular}{|c|c|c|c|c|c|c|c|c|c|c|c|c|c|c|c|c|c|}
\hline \multirow{3}{*}{ Generation } & \multicolumn{4}{|c|}{ Observed } & \multicolumn{2}{|c|}{ Total } & \multicolumn{4}{|c|}{ Expected } & \multicolumn{4}{|c|}{ Expected ratio } & \multicolumn{2}{|c|}{$\chi^{2}$} & \multirow{3}{*}{$\begin{array}{c}\text { Table } \chi 2 \\
\text { value at } \\
5 \% \text { with } 1 \text { df }\end{array}$} \\
\hline & \multicolumn{2}{|c|}{ PR } & \multicolumn{2}{|c|}{ AR } & \multirow{2}{*}{$\begin{array}{l}\text { PR } \\
\mathrm{C} 1 \\
\end{array}$} & \multirow{2}{*}{$\begin{array}{c}\mathbf{A R} \\
\mathrm{C} 2\end{array}$} & \multicolumn{2}{|c|}{ PR } & \multicolumn{2}{|c|}{ AR } & \multicolumn{2}{|c|}{ PR } & \multicolumn{2}{|c|}{ AR } & \multirow{2}{*}{$\begin{array}{c}\mathbf{P R} \\
\mathrm{C} 1\end{array}$} & \multirow{2}{*}{$\begin{array}{c}\mathbf{A R} \\
\mathrm{C} 2\end{array}$} & \\
\hline & $\mathrm{C} 1$ & $\mathrm{C} 2$ & $\mathrm{C} 1$ & $\mathrm{C} 2$ & & & $\mathrm{C} 1$ & $\mathrm{C} 2$ & $\mathrm{C} 1$ & $\mathrm{C} 2$ & $\mathrm{C} 1$ & $\mathrm{C} 2$ & $\mathrm{C} 1$ & $\mathrm{C} 2$ & & & \\
\hline $\mathrm{F}_{2}$ & 189 & 193 & 111 & 107 & 300 & 300 & 225 & 225 & 75 & 75 & 3 & 3 & 1 & 1 & $3.76^{\mathrm{NS}}$ & $3.55^{\mathrm{NS}}$ & \\
\hline $\mathrm{BC}_{1}$ & 38 & 28 & 22 & 32 & 60 & 60 & 30 & 30 & 30 & 30 & 1 & 1 & 1 & 1 & $2.13^{\mathrm{NS}}$ & $0.13^{\mathrm{NS}}$ & 3.84 \\
\hline $\mathrm{BC}_{2}$ & 51 & 49 & 4 & 11 & 60 & 60 & 60 & 60 & 0 & 0 & 1 & 1 & 0 & 0 & $1.35^{\mathrm{NS}}$ & $2.01^{\mathrm{NS}}$ & \\
\hline
\end{tabular}

PR - Presence of rachis $\quad A R-$ Absence of rachis $\mathrm{BC}_{1}-\mathrm{F}_{1}$ backcrossed to DDK-1025 $\mathrm{BC}_{2}-\mathrm{F}_{1}$ backcrossed to ML-1 NS - Non significance C1 - DDK-1025 X ML-1 C2 - DDK-1025 X ML-2 
Table.3 Mean and variance of parents F1, F2, BC1 and BC2 generations in respect of ten quantitative characters of two cross

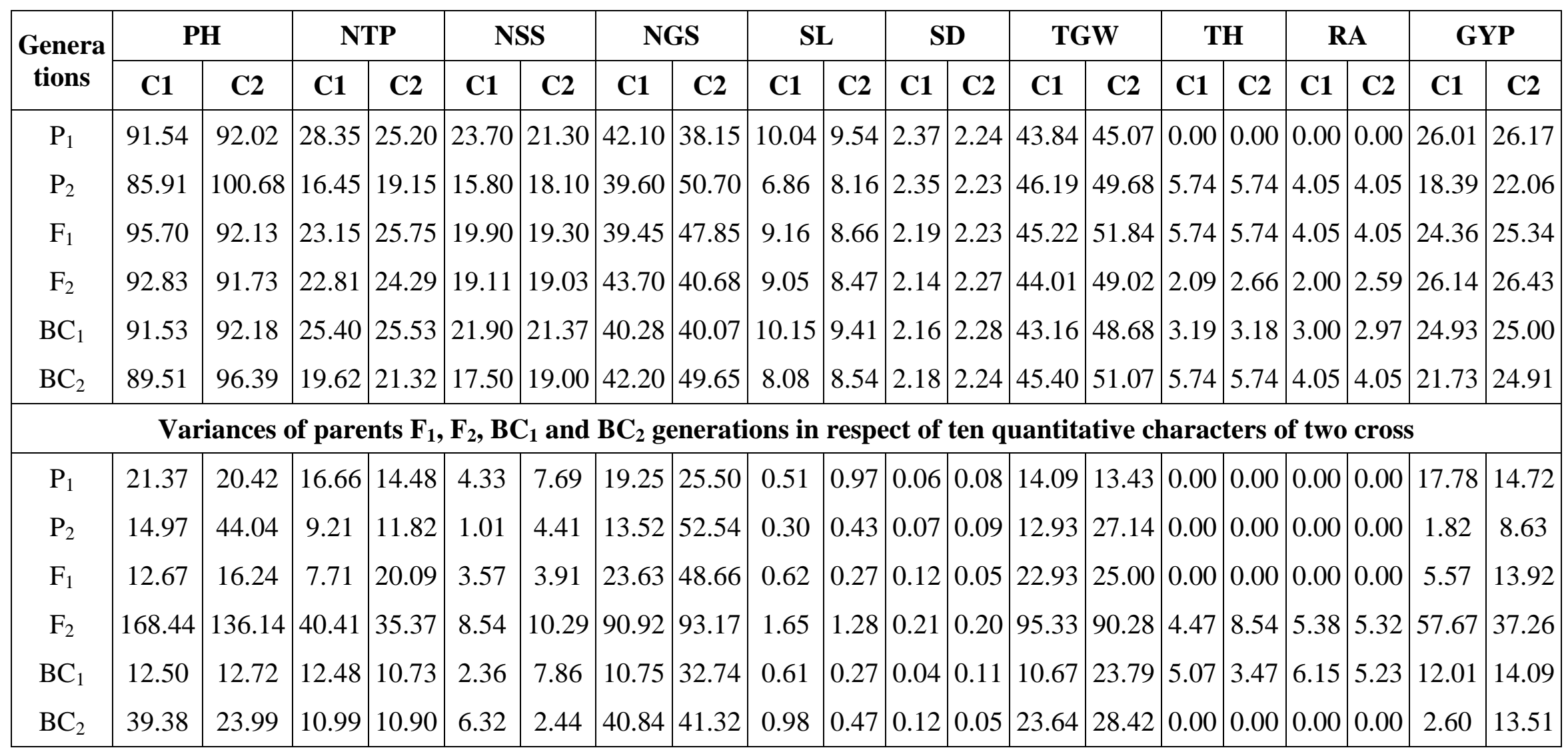

$\mathrm{PH}$ - Plant height $(\mathrm{cm})$

NTP - No. of tillers/plant NSS - No. of spikelets/spike

NGS - No. of grains/spike

SL - Spike length (cm)
SD - Spike density (cm) C1 DDK-1025 X ML-1

TGW- Thousand grain wt (g) C2 DDK-1025 X ML-2

TH - Threshability

RA - Rachis

$\mathrm{GYP}^{-}$Grain yield/plant (g) 
Table.4 Joint scaling test and estimates of gene effects for ten quantitative characters in two dicoccum cross: DDK-1025 x M11/ML-2

\begin{tabular}{|c|c|c|c|c|c|c|c|c|c|}
\hline Characters & & m & d & $\mathbf{h}$ & $\mathbf{i}$ & $\mathbf{j}$ & 1 & $\mathbf{x}$ & epistasis \\
\hline \multirow{2}{*}{$\begin{array}{l}\text { Plant height } \\
\text { (cm) }\end{array}$} & $\mathrm{C} 1$ & & $* \pm 0.93$ & $-2.30^{N S_{ \pm}}+3.68$ & $-9.27 * * \pm 3.53$ & $-0.80^{\mathrm{NS}} \pm 1.15$ & $16.04 * * \pm 5.21$ & $2.02 * *$ & Duplicate \\
\hline & $\mathrm{C} 2$ & $91.73 * * \pm 0.67$ & $-4.21 * * \pm 0.78$ & $5.98 * \pm 3.37$ & $10.21 * * \pm 3.12$ & $0.12^{\mathrm{NS}} \pm 1.19$ & $-10.38 * \pm 4.85$ & $11.48 * *$ & Duplicate \\
\hline \multirow{2}{*}{$\begin{array}{c}\text { No. of } \\
\text { tillers/plant }\end{array}$} & $\mathrm{C} 1$ & $=0.36$ & 0.625 & $-0.47^{\mathrm{NS}} \pm 2.10$ & $-1.22^{\mathrm{NS}_{ \pm}} 1.92$ & $-0.17^{\mathrm{NS}_{ \pm}} \pm .84$ & $2.29^{\mathrm{NS}} \pm 3.35$ & $1.313^{\mathrm{NS}}$ & Duplicate \\
\hline & $\mathrm{C} 2$ & $24.29 * * \pm 0.34$ & $4.22 * * \pm 0.60$ & $0.10^{\mathrm{NS}} \pm 2.15$ & $-3.47 * \pm 1.82$ & $1.19^{\mathrm{NS}} \pm 0.83$ & $5.62^{\mathrm{NS}} \pm 3.60$ & $5.76 * *$ & Complementary \\
\hline \multirow{2}{*}{$\begin{array}{l}\text { Spike length } \\
\quad(\mathrm{cm})\end{array}$} & $\mathrm{C} 1$ & $5 * * \pm 0.07$ & $2.07 * * \pm 0.16$ & $0.96 * \pm 0.48$ & $0.26^{\mathrm{NS}} \pm 0.44$ & $0.48 * * \pm 0.19$ & $-1.51 * \pm 0.82$ & $13.135 * *$ & Duplicate \\
\hline & $\mathrm{C} 2$ & $8.47^{* *} \pm 0.07$ & $0.87^{* *} \pm 0.11$ & $1.85^{* *} \pm 0.39$ & $2.04 * * \pm 0.34$ & $0.18^{\mathrm{NS}} \pm 0.17$ & $-2.94 * * \pm 0.62$ & $40.58 * *$ & Duplicate \\
\hline \multirow{2}{*}{$\begin{array}{c}\text { No. of } \\
\text { spikelets/spike }\end{array}$} & $\mathrm{C} 1$ & $19.11^{* *} \pm 0.16$ & $4.40 * * \pm 0.38$ & $2.49 * \pm 1.13$ & $2.34^{\mathrm{NS}} \pm 1.01$ & $0.45^{N S_{ \pm}} 0.46$ & $-1.84^{\mathrm{NS}_{ \pm} 1.93}$ & $11.852 * *$ & Duplicate \\
\hline & $\mathrm{C} 2$ & $19.03 * * \pm 0.19$ & $2.37 * * \pm 0.41$ & $-7.36 * * \pm 1.26$ & $0.77^{* *} \pm 1.11$ & $0.767^{\mathrm{NS}} \pm 0.57$ & $4.63 * * \pm 2.16$ & $17.85 * *$ & Duplicate \\
\hline \multirow{2}{*}{$\begin{array}{c}\text { No. of } \\
\text { grains/spike }\end{array}$} & $\mathrm{C} 1$ & $43.71 * * \pm 0.55$ & $-1.91 * \pm 0.92$ & $-11.23 * * \pm 3.14$ & $-9.83 * * \pm 2.87$ & $-3.16^{* *} \pm 1.12$ & $5.46^{\mathrm{NS}} \pm 4.99$ & $33.796 * *$ & \\
\hline & $\mathrm{C} 2$ & $40.68 * * \pm 0.56$ & $-9.58 * * \pm 1.11$ & $20.14 * * \pm 3.65$ & $16.71 * * \pm 3.15$ & $-3.31 * \pm 1.49$ & $-11.60 * \pm 6.19$ & $45.14^{* *}$ & Di \\
\hline \multirow{2}{*}{$\begin{array}{c}\text { Spike } \\
\text { density }(\mathrm{cm})\end{array}$} & $\mathrm{C} 1$ & $2.15^{* *} \pm 0.02$ & $-0.02^{\mathrm{NS}} \pm 0.05$ & $-0.05 * * \pm 0.17$ & $0.10^{\mathrm{NS}} \pm 0.14$ & $-0.03^{\mathrm{NS}_{ \pm}} 0.06$ & $0.30^{\mathrm{NS}} \pm 0.28$ & $6.842 * *$ & Duplic \\
\hline & $\mathrm{C} 2$ & $2.27 * * \pm 0.03$ & $0.04^{\mathrm{NS}} \pm 0.05$ & $-0.05^{\mathrm{NS}} \pm 0.16$ & $-0.05^{\mathrm{NS}_{ \pm}} \pm 0.15$ & $0.04^{\mathrm{NS}} * \pm 0.07$ & $-0.04^{\mathrm{NS}_{ \pm}} 0.27$ & $1.38^{\mathrm{NS}}$ & Complementary \\
\hline \multirow{2}{*}{$\begin{array}{l}\text { 1000-grain } \\
\text { weight (g) }\end{array}$} & $\mathrm{C} 1$ & $44.00 * * \pm 0.56$ & $-2.24 * * \pm 0.75$ & $1.30^{* *} \pm 2.97$ & $1.09^{\mathrm{NS}} \pm 2.71$ & $-1.06^{\mathrm{NS}} \pm 0.95$ & $2.23^{\mathrm{NS}} \pm 4.49$ & 3.7 & Complemen \\
\hline & $\mathrm{C} 2$ & $49.02 * * \pm 0.55$ & $-2.39 * * \pm 0.93$ & $7.88^{* *} \pm 3.17$ & $3.42^{\mathrm{NS}} \pm 2.88$ & $-0.09^{\mathrm{NS}_{ \pm}} \pm 1.17$ & $-4.50^{\mathrm{NS}} \pm 5.08$ & $14.2 * *$ & Duplicate \\
\hline \multirow{2}{*}{$\begin{array}{c}\text { Threshabilit } \\
\mathrm{y}\end{array}$} & $\mathrm{C} 1$ & $2.09 * * \pm 0.12$ & $-2.55 * * \pm 0.291$ & $12.38 * * \pm 0.75$ & $9.51 * * \pm 0.75$ & $0.32^{\mathrm{NS}} \pm 0.29$ & $10.14 * * \pm 1.26$ & $3.86 * *$ & Duplicate \\
\hline & $\mathrm{C} 2$ & $2.66^{* *} \pm 0.17$ & $-2.56^{* *} \pm 0.24$ & $10.08 * * \pm 0.83$ & $7.21^{* *} \pm 0.83$ & $0.32^{\mathrm{NS}} \pm 0.24$ & $7.84^{* *} \pm 1.18$ & $3.84 * *$ & Duplicate \\
\hline \multirow{2}{*}{$\begin{array}{c}\text { Grain } \\
\text { yield/plant (g) }\end{array}$} & $\mathrm{C} 1$ & $26.14 * * \pm 0.438$ & $3.19 * * \pm 0.49$ & $-9.08 \mathrm{NS} \pm 2.13$ & $-11.23 * * \pm 2.01$ & $-0.61 \mathrm{NS} \pm 0.69$ & $11.019 * * \pm 3.01$ & $34.69 * *$ & Duplicate \\
\hline & $\mathrm{C} 2$ & $26.43^{* *} \pm 0.35$ & $0.10 * * \pm 0.68$ & $-4.66 * * \pm 2.19$ & $-5.89 * * \pm 1.96$ & $-1.96 \mathrm{NS} \pm 0.87$ & $4.98 * * \pm 3.65$ & $17.55^{* *} *$ & Duplicate \\
\hline
\end{tabular}




\section{Plate.1}

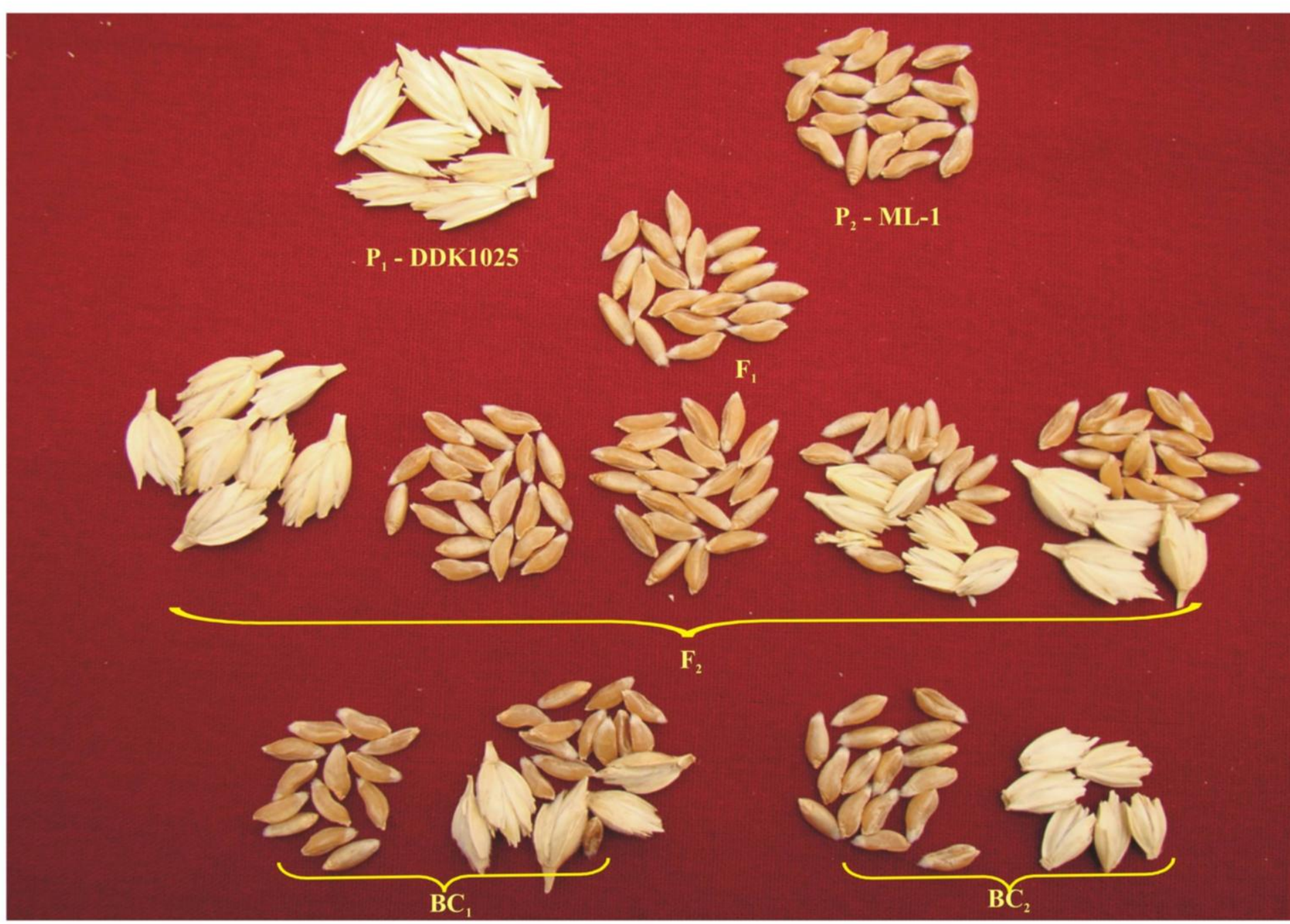

Plate 5: Morphological variation with respect to free threshable and non-free threshable seeds of parents $\mathrm{F}_{1}, \mathrm{~F}_{2}$ and $\mathrm{BC}_{1}, \mathrm{BC}_{2}$ generations of the cross DDK-1025 x ML-1 


\section{Plate.2}

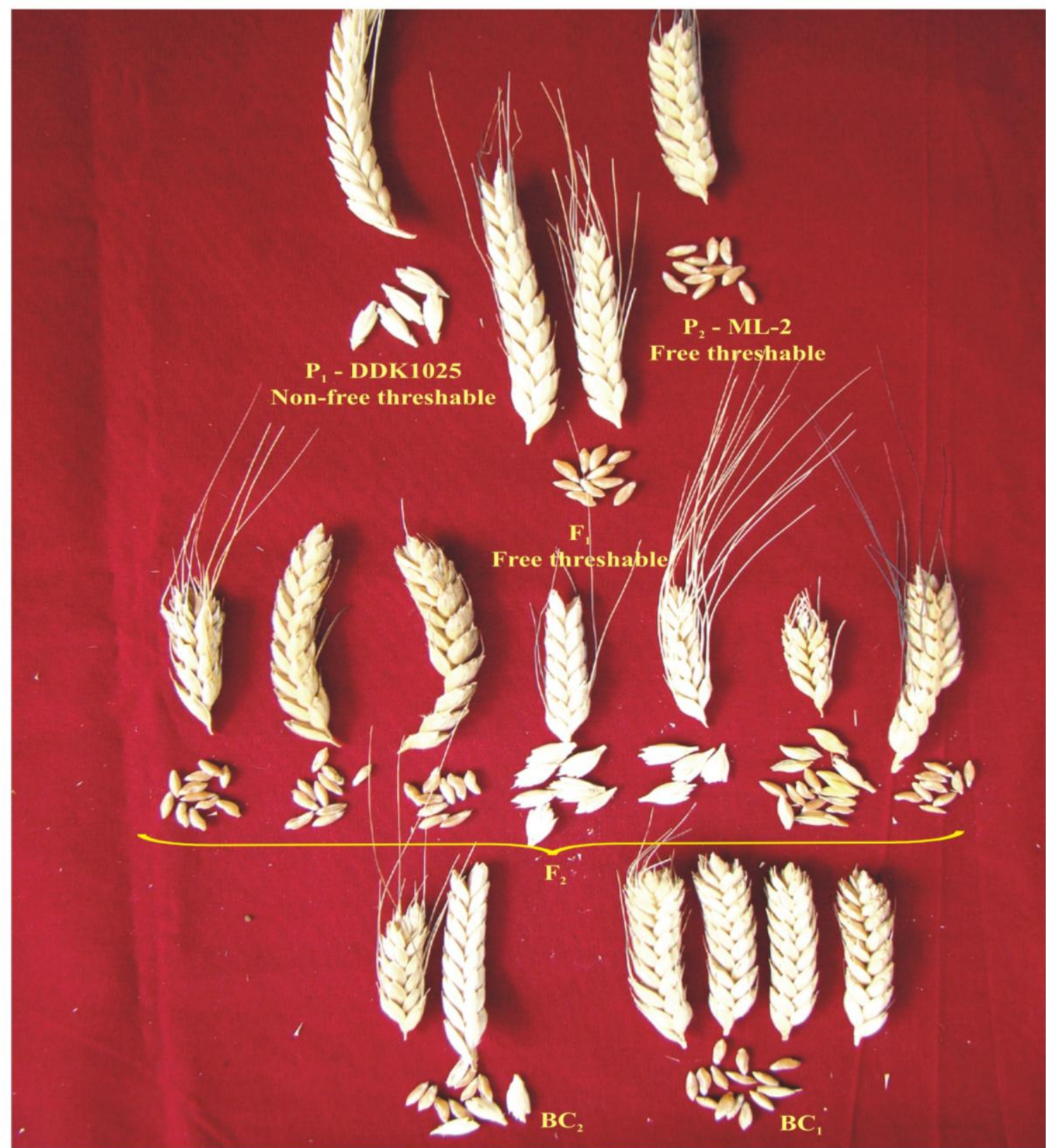

Plate 6: Morphological variation with respect to free threshability and non-free threshability seeds of parents $F_{1}, F_{2}$ and $B C_{1}, B C_{2}$ generations of the cross DDK-1025 x ML-2 
Among gene effects dominance gene action [h] played a major role for spike density. However, among epistatic interactions, additive $\mathrm{x}$ additive gene interaction in negative direction was greater than other two interactions indicating the importance of dominance and additive $\mathrm{x}$ additive gene effects for this trait in DDK-1025 x ML-2 cross. Whereas, in DDK-1025 x ML-1 cross, it has been noticed that only dominance gene effects were important in explaining the inheritance of this trait with complementary type of gene interaction. Similar gene effects were reported by Hussain et al., (1990). Mutant lines with mean grain weight of 46 and $49 \mathrm{~g}$ for thousand grains was much superior compared to the grain weight of DDK-1025 genotype (43 to $45 \mathrm{~g})$. Interestingly, very high influence of dominance gene effect was evident for thousand grain weight in the cross DDK-1025 $\mathrm{x}$ ML-2. The material therefore provides an excellent opportunity to improve grain weight as well as grain yield by employing hybridization programme. Yield per plant which is a primary interest of the breeders presented a complex picture as far as gene effects are concerned in both the crosses. It is interesting to note that all the gene effects were highly significant except additive $\mathrm{x}$ dominance effect in DDK-1025 $x$ ML-2 while, dominance and additive $\mathrm{x}$ dominance gene effects were non-significant in DDK1025 x ML-1. Being a complex trait, several workers like Siddique et al., (2004), Desai et al., (2005) and Ribadia et al., (2007) also reported that pre dominance of non additive gene effects of grain yield. Further, both dominance $[h]$ and dominance $\mathrm{x}$ dominance $[l]$ obtained positive signs depicting complementary nature of gene interaction in the cross DDK-1025 x ML-2.

Threshability is one of the important post harvest trait which is primary interest of the dicoccum breeders, presented a complex picture as far as gene effects are concerned in these two crosses. It is interesting to note that all the gene effects were highly significant except additive $\mathrm{x}$ dominance components in both crosses. The mean value of $F_{1}$ generation showed same as that of better parental mean of $\mathrm{P}_{2}$ indicating dominance for free threshability in both the crosses. Although, the additive and non-additive gene effects were found important, based on relative magnitude of $(d)$ and $(h)$, the dominance effect was found to play a major role for genetic control of this trait. Similar observations were evidenced by Villareal et al., (1996), Luo et al., (2000) and Patil (2010). Among the interaction effects, dominance $\mathrm{x}$ dominance effects $(l)$ was found most important. Duplicate epistasis was evident for inheritance of the trait. Since interaction effects were significant it was clear that in addition to the major free threshability gene (Q-gene), additional genes are involved in determining emmer wheat threshability. Peleg et al., (2011) found six QTLs for the trait threshability, which are located on different chromosomes (2B, 4A1, $4 \mathrm{~A} 2,4 \mathrm{~B}, 5 \mathrm{~A}$, and $7 \mathrm{~B}$ ) and concluded that more than one gene involved in expression of this trait in emmer wheat.

The opposite signs for dominance variance (h) and dominance $\mathrm{x}$ dominance (l) interactions in both the crosses for most of the traits have been observed. Whereas the crosses DDK-1025 x ML-1 for thousand grain weight and DDK-1025 x ML-2 cross for number of tillers per plant and spike density revealed epistatic effects indicating that duplicate type of epistasis play a role in the inheritance.

For the trait rachis, both the crosses exhibited dominance of presence of rachis over absence of rachis. Presence of rachis types are governed by the single dominant gene (Table 4). The results of the present study was 
supported by the reports of Cao et al., (1997) who reported brittle rachis and glume hardness have been regarded as pleiotropic effects of the spelt gene q.

Nevertheless, for both the crosses, introgression is likely to be more useful in the improvement of yield and some of its components in dicoccum wheat along with free threshability. DDK-1025 x ML-2 was the potential source for improving the threshability and yield. However, DDK-1025 $\mathrm{x}$ ML-1 may be regarded as potential source population for some of important yield component traits like number of spikelets per spike and spike length.

\section{References}

Cao, W.G., Scoles, C.L. and Hucl, P., 1997. The genetics of rachis fragility and glume tenacity in semi-wild wheat. Euphytica., 94: 119-124.

Desai, S.A., Lohithaswa, H.C., Hanchinal, R. R., Patil, B. N., Kalappanavar, I. K. and Math, K. K., 2005. Combining ability for quantitative traits in bread wheat (Triticum aestivum L.). Indian J. Genet. Plant Breed., 65(4): 311-312.

Dhadhal, B.A. and Dobariya, K.L. 2006. Combining ability analysis over environments for grain yield and its components in bread wheat (Triticum aestivum L.). Nat. J. Plant Improve., 8(2): 172-173.

Hayman, B.I. 1958. Separation of epistatic from additive and dominance variation in generation means. Heredity, 12: 371390.

Hussain, M. and Chowdhry, A.R. 1990. Estimation of heterosis and inheritance of some quantitative characters of economic importance in spring wheat crosses, Pakistan J. Agric. Sci., 27(4): 347-380.

Inamullah, Fida-Mohammad., Siraj-Ud-Din., Ghulam-Hussain. and Sardar, A. 2006.
Combining ability analysis for important traits in bread wheat, Sarhad J. Agril., 22(1): 45-50.

Ismail, A.A., Ahmed, T.A., Tawfils, M. B. and Khalifa, E.M.A. 2006. Gene action and combining ability analysis of diallel crosses in bread wheat under moisture stress and non-stress conditions. Assiut J. Agril. Sci., 37(2): 17-33.

Jag, S., Lakshmi, K., Singh, R.P., Shoran, J. and Kant, L. 2003. Winter and spring wheat: an analysis of combining ability. Cereal Res. Commun., 31: 3-4.

Jin Bao, Y., Guo Ca, Y., Yang, X., Qian, C. and Wang, S. 2004. Analysis on the combining ability and heritability of the spike characters in wheat. Acta Agric. Shanghai., 20(3): 32-36.

Kearsey, M.J., Pooni, H.S. 1996. The genetical analysis of quantitative traits. London: Chapman and Hall.

Kerber, E.R. and Rowland, G.G. 1974. Origin of the free threshing character in hexaploid wheat. Canadian J. Genet. Cyt., 16: 145-154.

Koumber, R.M. and El-Gammaal, A.A. 2012. Inheritance and gene action for yield and its attributes in three bread wheat crosses (Triticum aestivum L.). World J. of Agric. Sci., 8(2): 156-162.

Luo, M.C., Yong, Z.L. and Dvorak, J. 2000. The $\mathrm{Q}$ locus of manian on European spelt wheat. Theort. Appl. Genet., 100 602-606.

MacKey, J. 1966. Species relationship in Triticum, Proc. 2nd In-tern. Wheat Genet. Symp., Lund, Sweden, Hereditas (Suppl.)., 2: 237-276.

Mather, K. and Jinks, J.L. 1971. Biometrical genetics. Chapman and Hall Ltd., London.

Meena, B.S. and Sastry, E.V.D. 2003. Combining ability in bread wheat (Triticum aestivum L.). Annals Biol., 19(2): 205-208. 
Patil, L.C. 2010. Genetic analysis of spot blotch resistance, yield and yield attributing traits through interspecific (Triticum dicoccum (Schrank) Schulb x Triticum durum Desf.) hybridization in tetraploid wheat. Ph. D. Thesis, Univ. Agrilc. Scie, Dharwad.

Peleg, Z., Tzion, F., Abraham, B. K., Shaha, A. and Yehoshua, S., 2011. Genetic analysis of wheat domestication and evolution under domestication. $J$. of Experimental Bot., 1-11.

Ribadia, K.H., Ponika, H.P., Dobariya, K.L. and Jivani, L.L. 2007. Combining ability through line $\mathrm{x}$ tester analysis in macaroni wheat (Triticum durum Desf). J. Maharashtra Agril. Univ., 32(1): 3438.

Siddique, M., Shiraz, A., Malik, M.F.A. and Awan, S.I. 2004. Combining ability estimates for yield and yield components in spring wheat. Sarhad J. Agri., 20(4): 485-487.

Vanpariya, L.G., Chovatia, V.P. and Mehta, D.R. 2006. Combining ability studies in bread wheat (Triticum aestivum L.). Nat. J. Plant Improve., 8(2): 132-137.

Villareal, R.L., Mujeeb-Kazi, A. and Rajaram, S. 1996. Inheritance of threshability in synthetic hexploid (Triticum turgidum x Triticum tauschii) by $T$. aestivum crosses. Plant Breed., 115(5): 407-409.

Wei, L., Zheng, Y., XiuJin, L., Wei, Y. and Zehong, Y. 2003. Analysis of combining ability and heritability in some new cultivars/lines of wheat. $J$. Sichuan Agric. Univ., 21(3): 201-204.

\section{How to cite this article:}

C.H. Nagaraju, Desai, S.A. Suma, S. Biradar, Rudra Naik, V. Chetan C.K. and Sathisha. 2017. Genetics of Free Threshability and Yield Traits in Tetraploid Wheat. Int.J.Curr.Microbiol.App.Sci. 6(3): 1163-1173. doi: https://doi.org/10.20546/ijcmas.2017.603.135 